\title{
Rock magnetic characterization of ferrimagnetic iron sulfides in gas hydrate-bearing marine sediments at Site C0008, Nankai Trough, Pacific Ocean, off-coast Japan
}

\author{
Myriam Kars ${ }^{*}$ and Kazuto Kodama
}

\begin{abstract}
A high-resolution rock magnetic study was carried out in Integrated Ocean Drilling Program (IODP) Expedition 316 Hole C0008A located in the Megasplay Fault Zone of the Nankai Trough, SW offshore Japan, in order to document changes in magnetic properties throughout gas hydrate-bearing horizons. A total of 169 Pleistocene discrete samples were collected from 110 to $153 \mathrm{~m}$ core depth below sea floor (CSF), and their magnetic minerals concentration, grain size, composition, and rock magnetic parameters were estimated. Results showed the presence of iron oxides ((titano)-magnetite), iron sulfides (greigite and pyrrhotite), and their mixture, among which single-domain greigite is the most major magnetic mineral present in the samples. Two horizons containing ferrimagnetic iron sulfides (114.5-127.5 and 129.5-150 m CSF) covering almost the entire studied interval were identified, both associated with slight local pore water anomalies, suggesting occurrence of gas hydrates and anoxic conditions. These results are different from the neighboring Hole C0008C (215 m away from Hole C0008A) where four pore water anomalies and six iron sulfide-rich intervals were identified for the same time slice. Comparison of the lithology, physical properties, and geochemical data of the two boreholes at Site $\mathrm{C0008}$ suggests that a combination of processes (e.g., availability of reactive iron, microbial activity) is responsible for such laterally varying distribution of the ferrimagnetic iron sulfides.
\end{abstract}

Keywords: Iron sulfides; Greigite; Pyrrhotite; Gas hydrate; C0008; IODP Expedition 316; Nankai Trough

\section{Background}

Gas hydrates, composed mainly of methane, have been paid growing attention for the last decades because of their potential value as an energy resource (e.g., Kvenvolden 1993) and their possible impact on submarine landslides and climate change (Kennett et al. 2003). Low temperature, relatively high pressure, and sufficient concentration of methane are required for gas hydrate formation, although the mechanisms are not well understood (Hesse 2003).

Accretionary prisms, such as the Cascadia Margin (offshore Oregon, USA) and the Nankai Trough (SW Japan) are favorable locations for gas hydrates accumulation.

\footnotetext{
* Correspondence: jm-mkars@kochi-u.ac.jp

Center for Advanced Marine Core Research, Kochi University, B200 Monobe, Nankoku 783-8502, Japan
}

The Nankai accretionary complex off the coast of SW Japan is formed by the subduction of the Philippine Sea plate beneath the Eurasian plate along the Nankai Trough.

On seismic profiles, gas hydrates horizons are recognized by the occurrence of high amplitude bottom simulating reflectors (BSRs) that are regarded as the base of a gas hydrate stability field (e.g., Ashi et al. 2002). BSRs indicate the boundary between contrasting high velocity gas hydrates zone above and low velocity free gas zone below.

In the Nankai Trough, BSRs are continuous in the fore arc Kumano Basin and intermittent in the imbricate fault zone. No BSRs are recognized in the megasplay fault zone (MSFZ) and the frontal thrust zone of the Nankai accretionary prism (Kinoshita et al. 2011). Gas hydrates dissociate rapidly during drill core recovery, 
and their identification is mostly indirect. Various analytical approaches on cores and during drilling are indicative of gas hydrate occurrences such as isotopic and pore water anomalies (essentially chlorinity anomalies) (Hesse 2003), lower core temperature, well logging data (Collett 2001), heat flow and thermal anomalies (Yamano et al. 2014; Kinoshita et al. 2015), and characteristic rock magnetic variations (e.g., Housen and Musgrave 1996; Larrasoaña et al. 2007).

The magnetic index $\mathrm{D}_{\mathrm{JH}}$ characterizes the occurrence of fine-grained (single domain-pseudo single domain) magnetic iron sulfides (Housen and Musgrave 1996). It is defined as the hysteresis parameters ratio $\left(M_{\mathrm{rs}} / M_{\mathrm{s}}\right) /$ $\left(B_{\mathrm{cr}} / B_{\mathrm{c}}\right)$ with $M_{\mathrm{rs}}$ is the remanence at saturation, $M_{\mathrm{s}}$ is the magnetization at saturation, $B_{\mathrm{c}}$ is the coercive field, and $B_{\mathrm{cr}}$ is the remanent coercive field. In the Cascadia Margin marine sediments, $D_{J H}$ displays high values within low chlorinity zones and indicates the occurrence of gas hydrates (Housen and Musgrave 1996). Widespread occurrence of greigite $\left(\mathrm{Fe}_{3} \mathrm{~S}_{4}\right)$ and pyrrhotite $\left(\mathrm{Fe}_{7} \mathrm{~S}_{8}\right)$, associated with gas hydrates has later been reported in the Cascadia Margin (e.g., Musgrave et al. 2006; Larrasoaña et al. 2006; Larrasoaña et al. 2007).

Rock magnetic properties of gas hydrate-bearing sediments in the Nankai Trough at Site C0008 have been recently investigated. A high-resolution magnetic study in Hole C0008C $\left(33^{\circ} 12.7313^{\prime} \mathrm{N}, 136^{\circ} 43.6727^{\prime} \mathrm{E}\right.$; water depth $=2797 \mathrm{~m}$ ), drilled during Integrated Ocean Drilling Program (IODP) Expedition 316 by the D/V Chikyu (Kinoshita et al. 2009), has been conducted between 70 and $110 \mathrm{~m}$ core depth below sea floor (CSF) (i.e. 2867-2907 m below sea level) to document the downcore mineralogy, grain size, and concentration variations of the magnetic minerals through the gas hydrate horizons in Pleistocene sediments (Kars and Kodama 2015). The peaks of $\mathrm{D}_{\mathrm{JH}}$ outline six layers bearing greigite and/or pyrrhotite, separated by sediments containing mainly coarse-grained (titano)magnetite. Four of these layers correspond to intervals where pore water anomalies were identified and hence correspond undoubtedly to gas hydrate horizons. The two remaining intervals are believed to be also gas hydrate horizons that were not identified by pore water geochemistry because of the low sampling resolution for pore water analysis. The downcore variations of the magnetic properties in Hole C0008C have been explained by different diagenetic stages related to upward gas migration (Kars and Kodama 2015).

In this paper, a similar rock magnetic study has been carried out in Hole C0008A $\left(33^{\circ} 12.8229^{\prime} \mathrm{N}, 136^{\circ}\right.$ $43.5997^{\prime} \mathrm{E}$; water depth $=2751 \mathrm{~m}$ ), located $215 \mathrm{~m}$ apart from Hole C0008C and drilled during the same IODP expedition, in order to identify ferrimagnetic iron sulfides associated with gas hydrate occurrences (Fig. 1). Results from Hole C0008A show the occurrence of two thick layers containing ferrimagnetic iron sulfides, covering almost the entire studied interval. This contrasts with the results obtained in Hole C0008C. Possible leads are proposed to understand the distribution of the ferrimagnetic iron sulfide at Site C0008.

\section{Methods}

In this study, 169 discrete samples (7 cc plastic cubes) were collected at approximately $20-\mathrm{cm}$ interval covering the 110-153 m CSF depth interval on sections $13 \mathrm{H}-1$ to 19H-3 of Hole C0008A (2861-2904 mbsl). Slope sediments at Site $\mathrm{C0008}$ are divided into three stratigraphic units (Ia, Ib, Ic) (Fig. 1). The samples studied in this paper belong to unit $\mathrm{Ib}$ that is constituted of hemipelagic silty clays interbedded with coarse turbidite and fine ash layers (Kimura et al. 2011; Strasser et al. 2011). The mean grain size at Site C0008 is $5-12 \mu \mathrm{m}$, with values up to $20 \mu \mathrm{m}$ (Kopf et al. 2011). Based on the occurrence of calcareous nannofossils, the age of the collected samples ranges between 1.34 Ma at $90.39 \mathrm{~m} \mathrm{CSF}$ and $1.46 \mathrm{Ma}$ at $152.69 \mathrm{~m}$ CSF (Mid Pleistocene) (Expedition 316 Scientists 2009). This is supported by the onboard magnetostratigraphy that yields an age between 1.24 and $1.77 \mathrm{Ma}(\mathrm{C} 1 \mathrm{r} .2 \mathrm{r}$ ) (Expedition 316 Scientists 2009). The sampling depth includes two pore water chlorinity minima at $\sim 120$ and 136 m CSF (Expedition 316 Scientists 2009).

Magnetic measurements were performed at the paleomagnetic laboratory of the Center for Advanced Marine Core Research (CMCR), Kochi University, Japan. Low field-low frequency magnetic susceptibility $(\mathrm{X})$ was measured with a MS2 Bartington apparatus. Natural remanent magnetization (NRM) and anhysteretic remanent magnetization (ARM) were measured with a 2G SQUID cryogenic magnetometer in the shielded room (noise level $\sim 10^{-10} \mathrm{Am}^{2}$ ). ARM was imparted in a direct current (DC) bias field of $50 \mu \mathrm{T}$ in presence of an $80 \mathrm{mT}$ peak alternating field. Isothermal remanent magnetization (IRM) was subsequently imparted at 0.9 and $1.2 \mathrm{~T}$ by using a MMPM10 impulse magnetizer before being measured at each step with a Natsuhara Giken spinner magnetometer (noise level $\sim 10^{-8} \mathrm{Am}^{2}$ ). Then, the samples were subsequently remagnetized in a DC reverse field of $0.3 \mathrm{~T}$ and measured again, in order to calculate the S-ratio $\mathrm{S}=$ $\left(-\mathrm{IRM}_{-0.3 \mathrm{~T}}\right) / \mathrm{IRM}_{1.2 \mathrm{~T}}$, an indication of the relative proportion of hard coercive minerals (e.g., hematite, goethite, ferrimagnetic iron sulfides) in a mixture with soft ferrimagnetic minerals (e.g. magnetite, maghemite).

Hysteresis loops with a maximum applied field of $1 \mathrm{~T}$ were measured at room temperature with a Princeton Vibrating Sample Magnetometer (VSM) (noise level $\sim 10^{-7} \mathrm{Am}^{2}$ ). First order reversal curves (FORC) were also measured for 76 selected samples every $5-10 \mathrm{~cm}$, with a 1-T saturating field (averaging time $200 \mathrm{~ms}$, field 


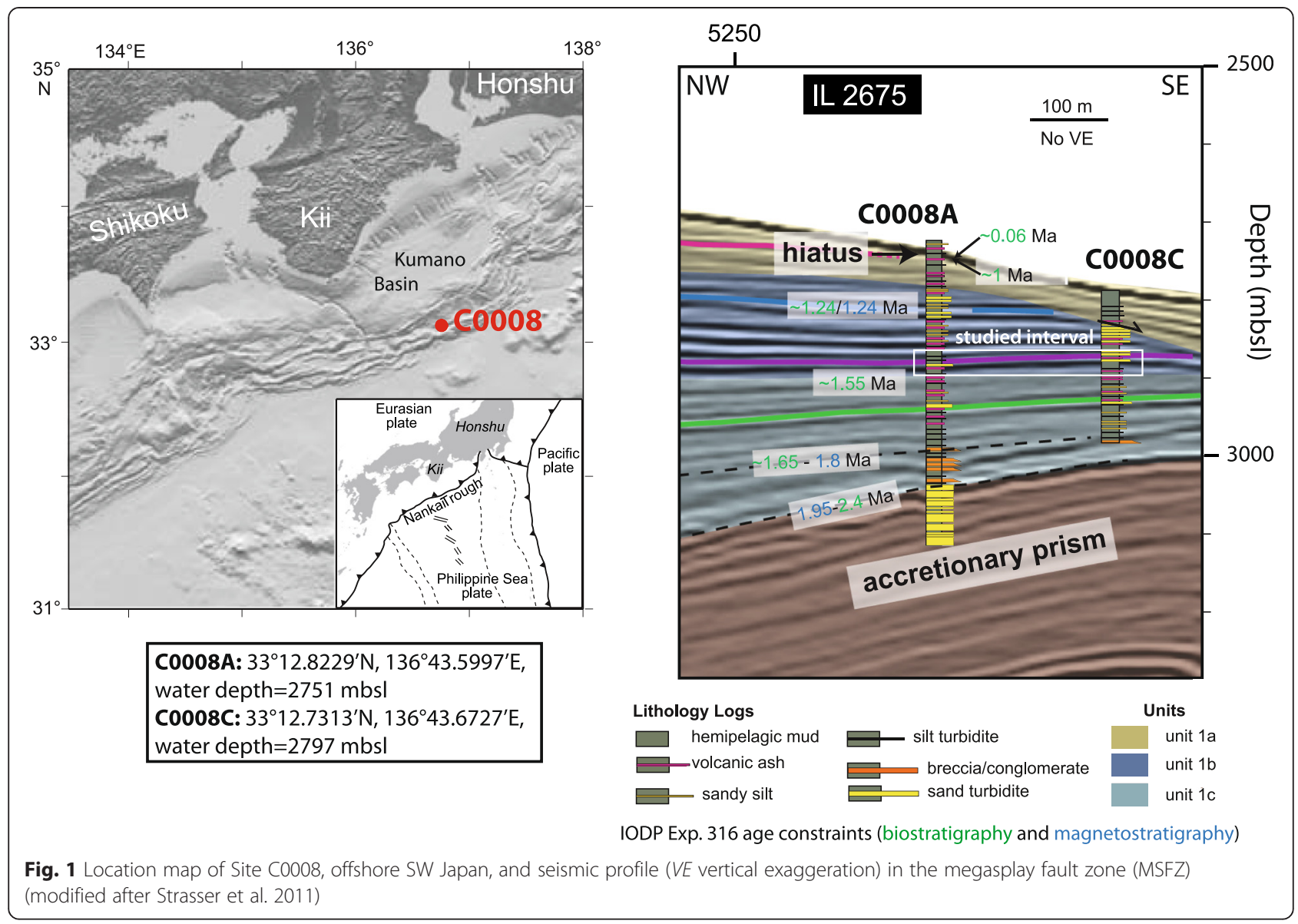

increment $5 \mathrm{mT}$, slew rate limit $1 \mathrm{~T} / \mathrm{s}$, number of FORCs 66). FORC diagrams were processed by using the software FORCInel (Harrison and Feinberg 2008).

Low-temperature measurements (down to $5 \mathrm{~K}$ ) were made with a Quantum Design Magnetic Properties Measurements System (MPMS) (noise level $\sim 10^{-10} \mathrm{Am}^{2}$ ) for 21 selected samples representing the three types of magnetic assemblages (described hereafter) and covering the entire studied interval. A cooling-warming cycle of a saturation isothermal remanent magnetization (SIRM) imparted at room temperature $(300 \mathrm{~K})$ at $2.5 \mathrm{~T}$ was first measured in a zero magnetic field (trapped field $<150 \mu \mathrm{T}$ ). A low temperature (LT)-SIRM was imparted at $5 \mathrm{~K}$ at $2.5 \mathrm{~T}$. The sample was then warmed up to room temperature in a zero magnetic field and measured (called ZFC for zero field cooled). The sample is then cooled down to $5 \mathrm{~K}$ in a $2.5 \mathrm{~T}$ magnetic field, and the LT-SIRM is measured during warming to $300 \mathrm{~K}$ (FC for field cooled).

\section{Results}

\section{NRM, $x, A R M / x$, and S-ratio}

The magnetic susceptibility $X$ is low throughout the studied interval $\left(<15 \times 10^{-8} \mathrm{~m}^{3} / \mathrm{kg}\right)$, except for six samples where $X$ is higher (Fig. 2b). Natural remanent magnetization (NRM) is remarkably constant and generally low $\left(<15 \mu \mathrm{Am}^{2} / \mathrm{kg}\right)$ throughout the studied interval, except for 119.5-120.5 and 136-137.5 m CSF depth ranges where NRM is $>15 \mu \mathrm{Am}^{2} / \mathrm{kg}$ (Fig. 2c). The highest values of the NRM $\left(>25 \mu \mathrm{Am}^{2} / \mathrm{kg}\right)$ likely correspond to samples containing ash particles (although care was taken to sample away from the ash layers). Nevertheless, NRM and $X$ are generally very low and constant over the studied depth range. This suggests that the non-ferrimagnetic portion may be significant.

The ARM/X ratio, an indicator of the grain size variations, shows, unlike NRM and $X$, greater variations and varies from $\sim 50$ to $\sim 1170 \mathrm{~A} / \mathrm{m}$ (Fig. $2 \mathrm{~d}$ ). The higher values of $\mathrm{ARM} / \mathrm{X}$ span two depth intervals, 115-122 and 135-140 m CSF, and suggest the occurrence of finegrained particles. However, because $X$ is low, it might be possible that this ratio may reflect both grain size and ferrimagnetic concentration.

The S-ratio generally displays high values above 0.9 , suggesting the dominance of low coercive magnetic minerals (Fig. 2e). The intervals $110-113$ and 127.5-129.5 m CSF are characterized by lower S-ratio values $(\sim 0.85)$. 


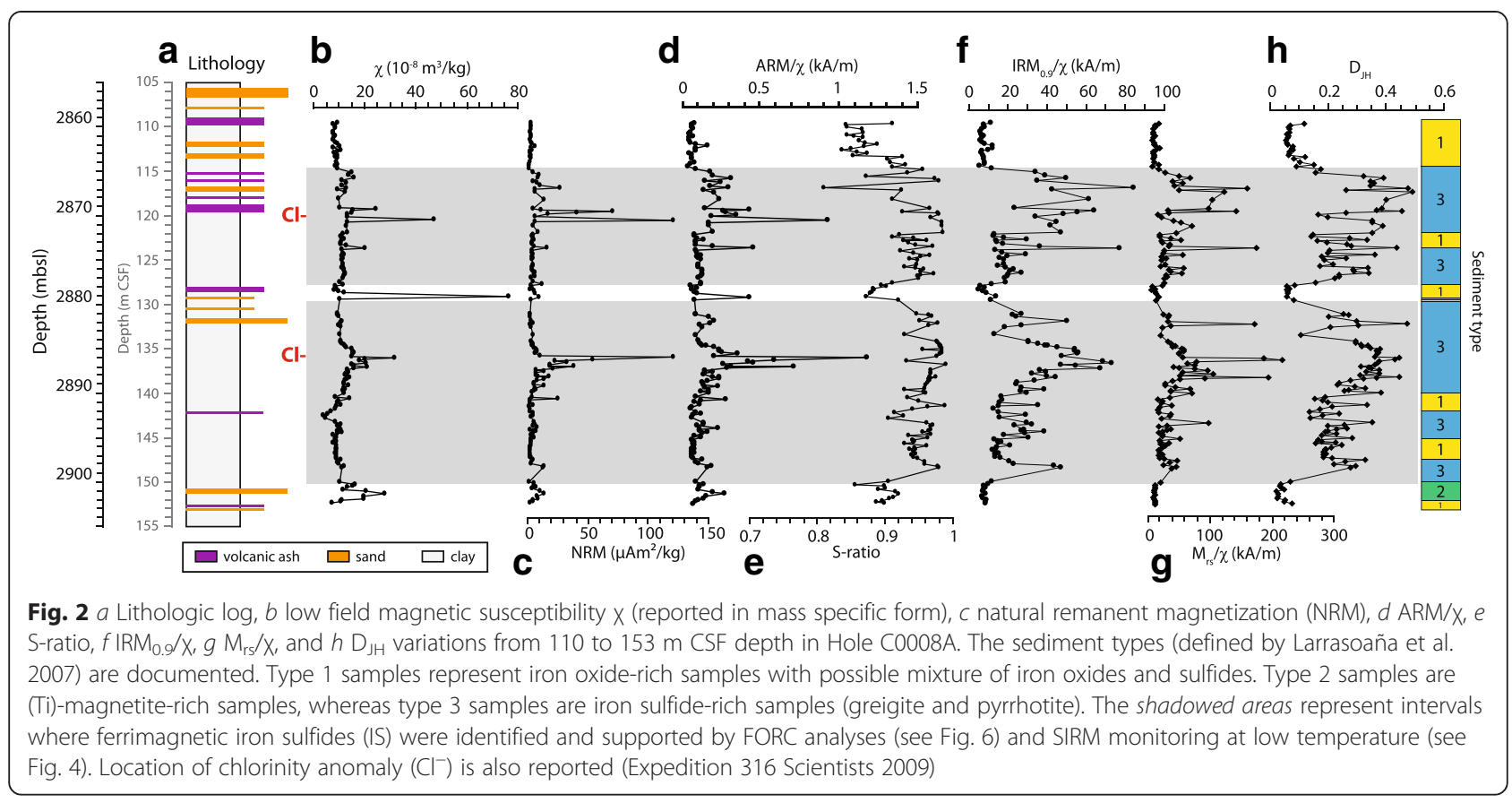

\section{$\mathrm{IRM}_{0.9} / \mathrm{X}$ ratio}

IRM/X ratio has been used to identify at first order greigite (e.g., Roberts 1995) and pyrrhotite (Housen and Musgrave 1996). The $I R M_{0.9} / X$ ratio, where $I_{0.9}$ is the IRM imparted at $0.9 \mathrm{~T}$, has been proposed as an indicator of magnetic assemblages occurring in gas hydrate environments (Larrasoaña et al. 2007). Three different types have been defined. They are all identified in Hole C0008C (Kars and Kodama 2015) and also recognized in Hole C0008A, with respect to their $X$ and $\mathrm{IRM}_{0.9} / \mathrm{X}$ values (Fig. 3). The

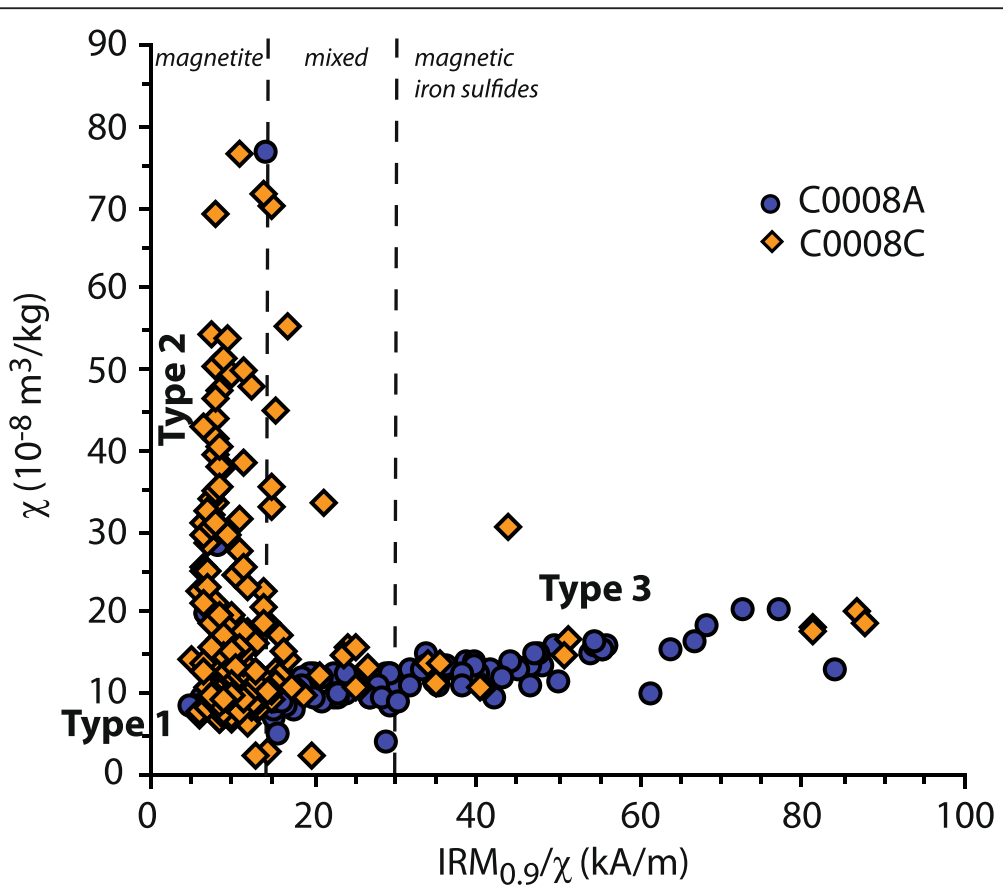

Fig. 3 X versus IRM $\mathrm{I}_{0.9} / X$ diagram. Type 1 (low $x$ and low IRM $\mathrm{M}_{0.9} / \mathrm{X}$ ) is mainly dominated by (Ti)-magnetite but can be a mixture of iron oxides and ferrimagnetic iron sulfides. Type 2 (high $x$ and low IRM.9/X) corresponds to samples containing mainly iron oxides (magnetite, titanomagnetite). Type 3 (low $x$ and high $\mid \mathrm{RM}_{0.9} / \mathrm{X}$ ) corresponds to samples containing mainly ferrimagnetic iron sulfides (greigite and pyrrhotite). The sample types are defined according to Larrasoaña et al. (2007). Data from Hole C0008A are from this study; data from Hole C0008C are from Kars and Kodama (2015) 
low $\mathrm{X}$ and low $\mathrm{IRM}_{0.9} / \mathrm{X}$ type 1 samples, composed of a mixture of iron oxides and iron sulfides, represent the majority of the samples, similar to the finding in Hole C0008C. With the exception of a few type 2 samples (with (titano)-magnetite as the dominant mineralogy), the remaining specimens belong to the type 3 which is characterized by low $X$ and high $\mathrm{IRM}_{0.9} / \mathrm{X}$. Some samples possess too high $\mathrm{IRM}_{0.9}$ values to be measured by the magnetometer and probably belong to type 3. Ferrimagnetic iron sulfides, i.e., greigite and pyrrhotite, compose the type 3 samples. From Fig. 3, it is clear that type 3 samples are by far more abundant in Hole C0008A compared to Hole C0008C for the same lateral horizon.

\section{Low-temperature measurements}

The low-temperature measurements performed on samples from Hole C0008A display similar results than those of Hole C0008C (Kars and Kodama 2015). The three types of magnetic assemblage, defined by the $\mathrm{IRM}_{0.9} / \mathrm{X}$ value and $X$, show characteristic low-temperature behavior (Fig. 4).
For type 1 samples, the Verwey transition of magnetite is not well marked and occurs at $\sim 110-115 \mathrm{~K}$ on the RT-SIRM curves (Fig. 4a; Muxworthy and McClelland 2000; Özdemir et al. 2002). During warming of the RTSIRM, the remanence is not fully recovered when passing the temperature of the Verwey transition. The transition is hardly visible on ZFC and FC curves (Fig. 4b). Similarly to Hole C0008C (Kars and Kodama 2015) and nearby Site C0004 in the MSFZ (Zhao and Kitamura 2011), between 50 and $60 \%$ of the LT-SIRM imparted at $5 \mathrm{~K}$ is lost upon warming between 5 and $35 \mathrm{~K}$ (Fig. 4b), suggesting the presence of very small magnetic (superparamagnetic) particles (e.g., Passier and Dekkers 2002).

Type 2 samples, contrary to the samples from types 1 and 3 , display a very well developed Verwey transition on the RT-SIRM (Fig. 4c) that are also recognizable on both ZFC and FC (Fig. 4d). The transition occurs at $120 \mathrm{~K}$ suggesting stoichiometric magnetite, probably of pseudo-single domain (PSD) to multidomain (MD) size, because the remanence is not fully recovered upon warming of the RT-SIRM.

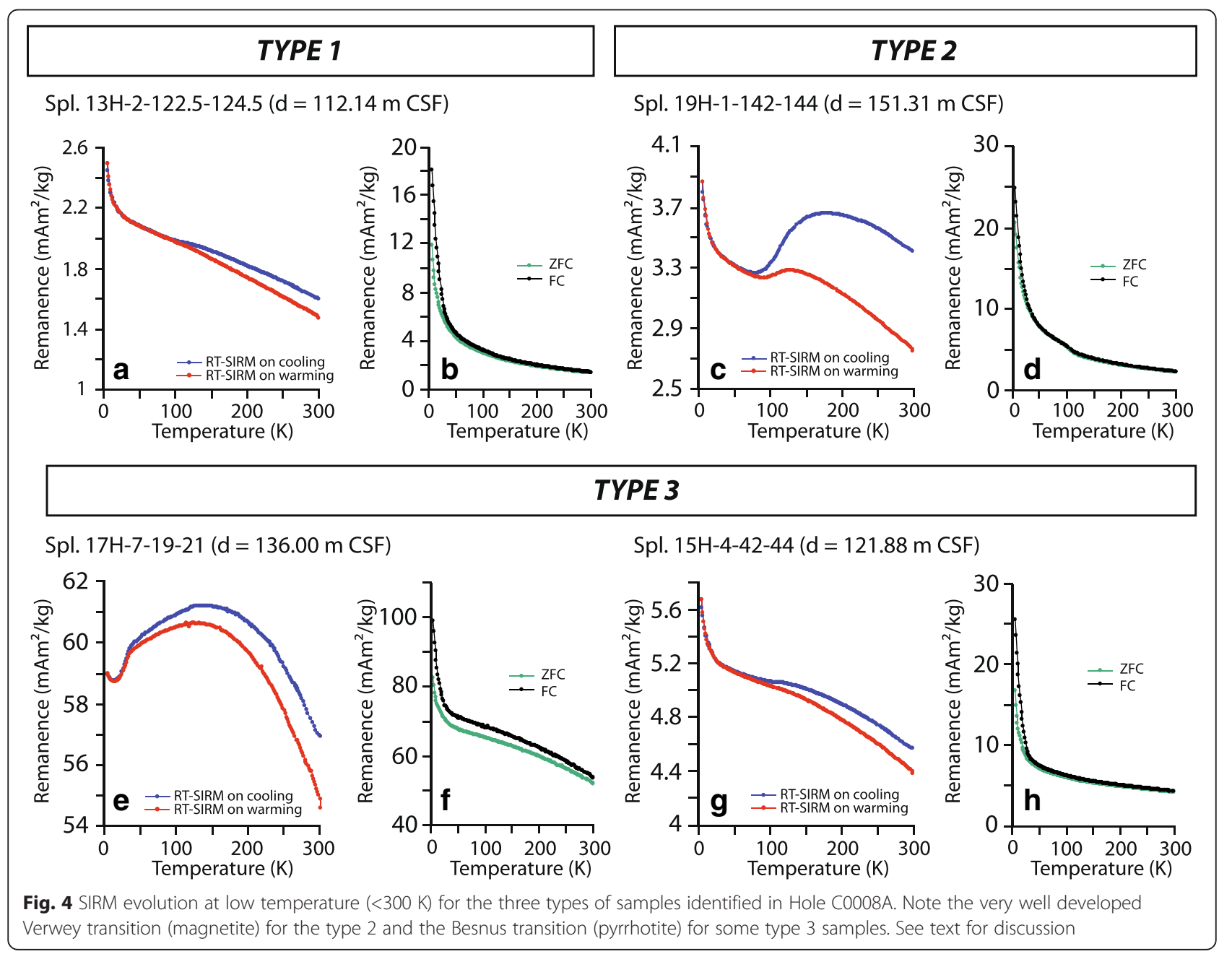


For the type 3 samples containing iron sulfides, two different low-temperature behaviors can be identified. One is characterized by the occurrence of the Besnus transition of pyrrhotite at $\sim 35 \mathrm{~K}$ on cooling of the RT-SIRM (Fig. 4e) (Dekkers et al. 1989; Rochette et al. 1990; Wolfers et al. 2011). The grain size of the pyrrhotite is probably single domain (SD) because the remanence is almost fully recovered upon warming of the RT-SIRM (Dekkers et al. 1989; Rochette et al. 1990). No particular feature can be identified on ZFC and FC (Fig. 4f). The second magnetic signature of type 3 samples is similar to that of type 1 samples (Figs. 4g, h). These samples contain mainly greigite that does not have low-temperature magnetic transition (Roberts et al. 2011).

For all types of the samples, the rapid increase observed at very low temperature $(<50 \mathrm{~K})$ on the RT-SIRM is actually an induced magnetization caused by the trapped magnetic field inside the MPMS and a strong paramagnetic contribution of the samples (e.g., clays) or submicron pyrrhotite (Aubourg and Pozzi 2010; Kars et al. 2011).

By assuming that all the studied samples contain detrital magnetite, Kars and Kodama (2015) proposed that the three magnetic assemblages (type 1, 2, or 3) can be distinguished by their $\delta_{\mathrm{ZFC}}$ and $\delta_{\mathrm{FC}}$ values (Moskowitz et al. 1993). The measured samples follow a 1:1 line and are distributed along this line. Low-temperature measurement conducted on samples from Hole C0008A support the findings in Hole C0008C (Fig. 5). As proposed by Kars and Kodama (2015), this distribution reflects the difference in magnetite concentration with respect to the presence of ferrimagnetic iron sulfides. The ratio magnetite/iron sulfide is then more important in type 2 samples (with high $\delta_{\mathrm{ZFC}}$ and $\delta_{\mathrm{FC}}>0.4$ ) and less important in type 3 samples (with low $\delta_{\mathrm{ZFC}}$ and $\delta_{\mathrm{FC}}<0.18$ ). However, this distinction is valid only for the samples studied in this context. $\delta_{\mathrm{ZFC}}$ and $\delta_{\mathrm{FC}}$ by the definition itself may involve different processes that are not related to iron oxides/sulfides ratio.

\section{FORC diagrams}

The magnetic mineralogy of the samples is confirmed by the use of FORC diagrams (Fig. 6). As expected for type 1 samples, low coercivity SD to PSD $\left(B_{\mathrm{c}} \sim 15 \mathrm{mT}\right)$ magnetite is identified by FORC analysis (Figs. 6a, b). Type 1 samples can also present a mixture of both iron oxides and iron sulfides. For instance, the sample on Fig. 6c shows clearly a mixture of SD magnetite $\left(B_{\mathrm{c}} \sim 15 \mathrm{mT}\right)$ and high coercivity SD greigite $\left(B_{\mathrm{c}} \sim 65 \mathrm{mT}\right)$ (Roberts et al. 2006). Type 2 samples seem to present coarser magnetite grains, as suggested by the FORC diagram on Fig. 6d showing PSD to MD magnetite (e. g., Roberts et al. 2000; Roberts et al. 2014). The most common feature in the analyzed samples is the occurrence for type 3 samples of high coercivity SD greigite (B $\sim 60-65 \mathrm{mT}$ ) (Fig. 6e-h) (e.g., Aben et al. 2014; Chang et al. 2014). Only four analyzed type 3 specimens show SD pyrrhotite characterized by its typical kidney shape (Fig. 6i) with a peak coercivity of $\sim 20 \mathrm{mT}$ (Wehland et al. 2005). The magnetic mineralogy from FORC analysis on Hole C0008A samples is similar to that of Hole C0008C specimens, although type 1 samples in Hole C0008A seem to present finer grained magnetite.

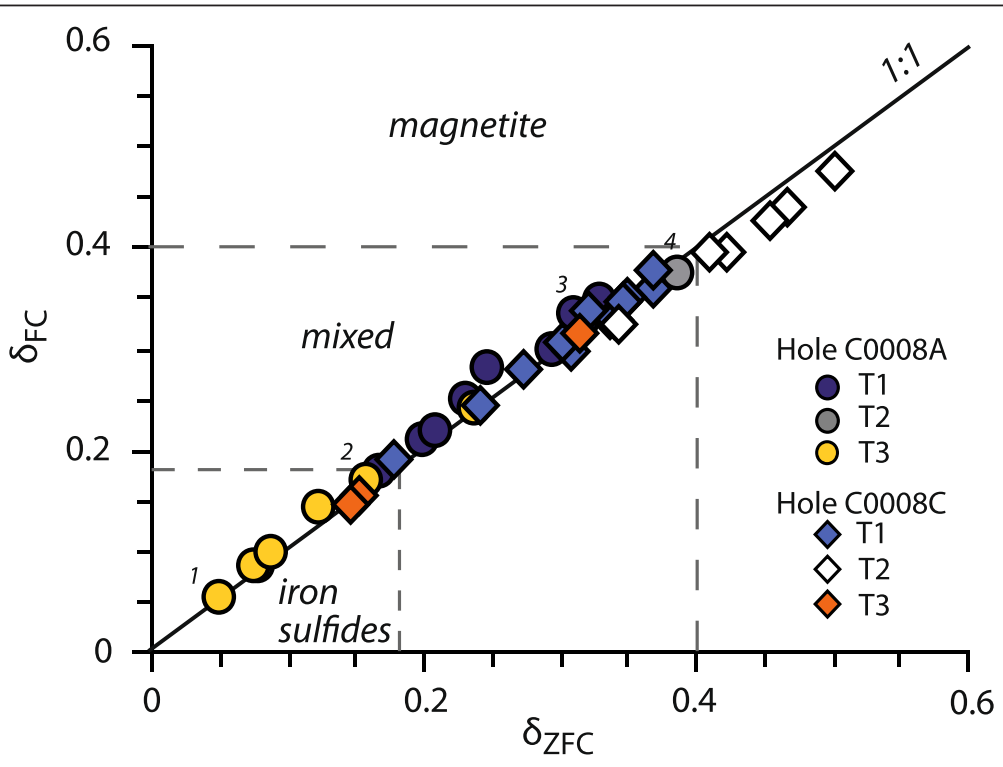

Fig. $5 \delta_{F C}$ versus $\delta_{Z F C}$ diagram. $\delta=\left(M_{80 K}-M_{150 K}\right) / M_{80 K}$ where $M$ is the remanence at low temperature (Moskowitz et al. 1993). Note the distribution of the $\delta$ values according to the samples types (T1, T2 and T3). Data from Hole C0008A are from this study; data from Hole C0008C are from Kars and Kodama (2015) 1, 2, 3 and 4 on the 1:1 line refer respectively to the samples 17H-7-19-21, 15H-4-42-44, 13H-2-122.5-124.5 and 19H-1-142-144 shown on Fig. 4. 


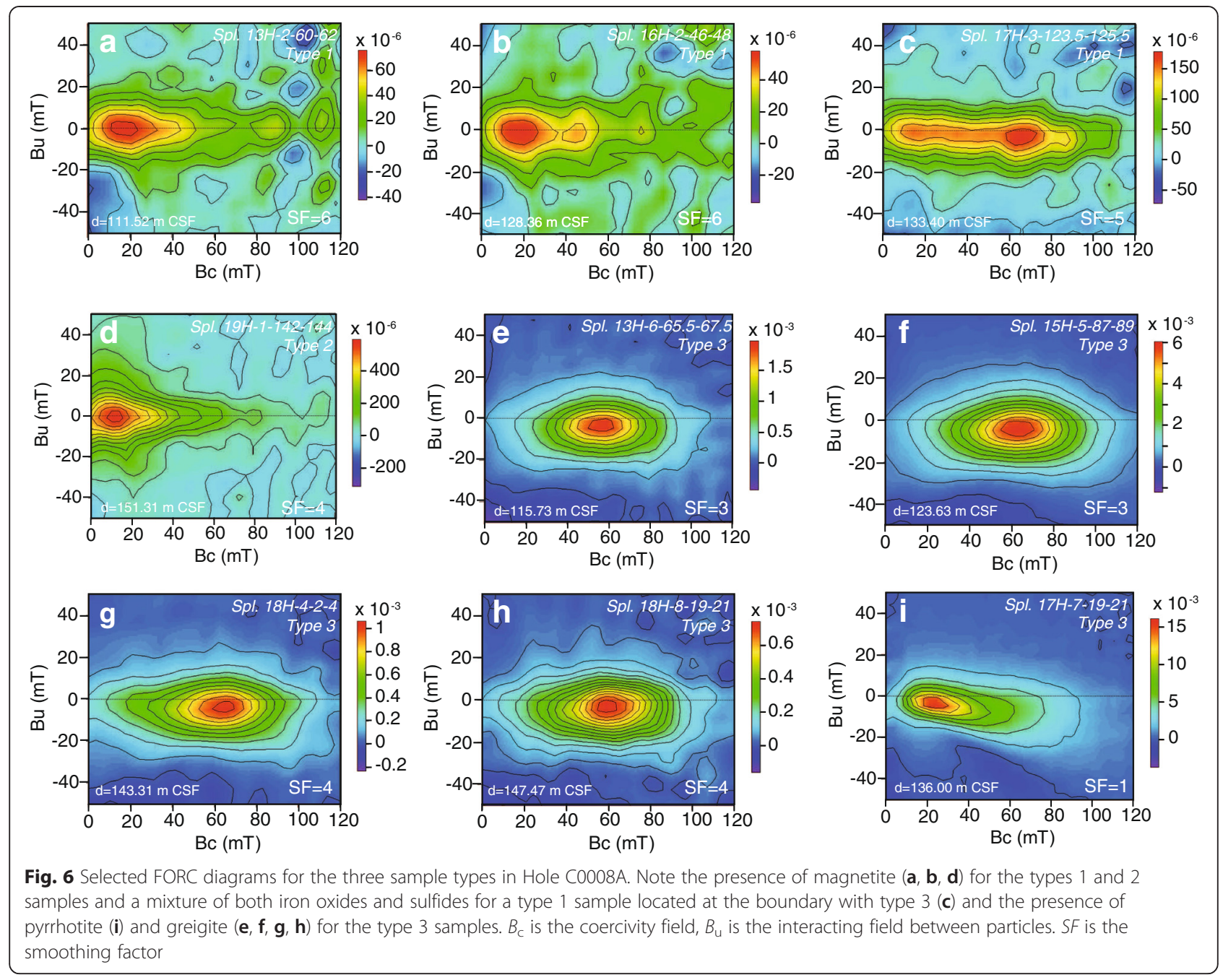

\section{Hysteresis properties and $D_{\mathrm{JH}}$}

The hysteresis properties, $M_{\mathrm{rs}}, M_{\mathrm{s}}, B_{\mathrm{cr}}$ and $B_{\mathrm{c}}$, of the samples, show downcore variations (see Additional file 1). Especially, $B_{\mathrm{cr}}$ and $B_{\mathrm{c}}$ show higher values in the $\sim 116-$ 127.5 and $\sim 131-148 \mathrm{~m}$ CSF depth intervals. The hysteresis ratios, $M_{\mathrm{rs}} / M_{\mathrm{s}}$ and $B_{\mathrm{cr}} / B_{\mathrm{c}}$, plotted on the Day plot (Day et al. 1977), show a hyperbolic distribution of the grain size from SD to MD. The great majority of the samples lay on the pseudo-single domain (PSD) domain (Fig. 7). Unlike the results of the studied samples of Hole C0008C (Kars and Kodama 2015), the few type 2 samples do not show distinct hysteresis properties, compared to types 1 and 3 samples.

As indicated by the IRM measurements (Fig. 3) and FORC analyses (Fig. 6), ferrimagnetic iron sulfides (greigite and pyrrhotite) are abundant in the samples. The index $\mathrm{D}_{\mathrm{JH}},\left(M_{\mathrm{rs}} / M_{\mathrm{s}}\right) /\left(B_{\mathrm{cr}} / B_{\mathrm{c}}\right)$, derived from the hysteresis properties and sensitive to the occurrence of finegrained ferrimagnetic iron sulfides, is reported on Fig. 7. The samples displaying high $\mathrm{D}_{\mathrm{JH}}$ values $>0.2$ belong to two intervals ( 116-128 and 130-148 m CSF) that host all type 3 samples and some type 1 samples (probable mixture of both iron oxides and ferrimagnetic iron sulfides) (Fig. 2h). This finding suggests that these two depth ranges that represent almost the entire studied interval are constituted of fine-grained (SD) ferrimagnetic iron sulfides.

\section{Discussion}

The studied interval in Hole C0008A roughly laterally correspond to the 70-110 m CSF (2867-2907 mbsl) interval in Hole C0008C studied previously by the authors (Kars and Kodama 2015). No correlation between the two holes was attempted by the IODP Expedition 316 Scientists because of the distance between the holes (215 $\mathrm{m}$ apart), presence of normal faults, and possible slumped sediments in Hole C0008A (e.g., Kinoshita et al. 2009; Strasser et al. 2011). One motivation for the magnetic study of Hole C0008A was to use the rock 


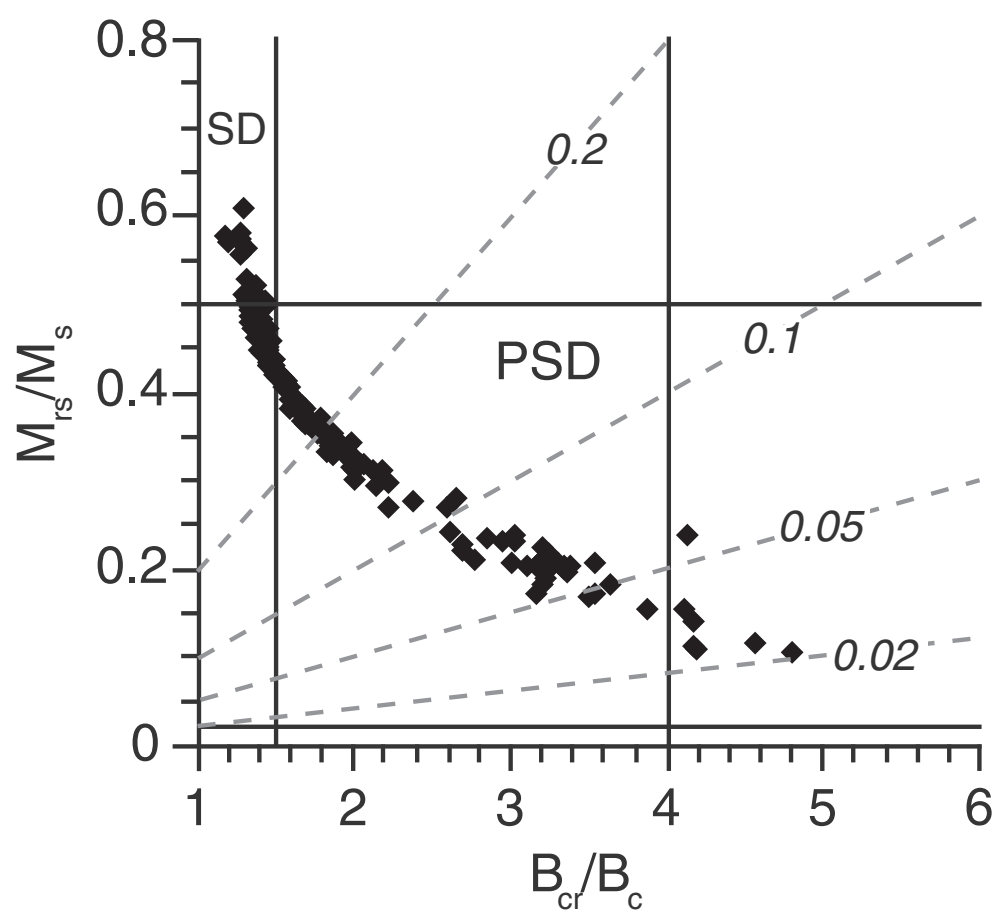

Fig. 7 Day plot for samples from Hole C0008A (Day et al. 1977). The dashed lines refer to $D_{J H}$ values

magnetic properties of the sediments in order to correlate Holes C0008A and C0008C.

Distribution of the ferrimagnetic iron sulfides, Site C0008 Based on the occurrence of the peaks of $\mathrm{D}_{\mathrm{JH}}$, high values of $M_{\mathrm{rs}} / \mathrm{X}(>40 \mathrm{kA} / \mathrm{m})$ and $\mathrm{IRM}_{0.9} / \mathrm{X}(>15-85 \mathrm{kA} / \mathrm{m})$, two intervals containing ferrimagnetic iron sulfides, referred as IS (for Iron Sulfides) layers hereafter, are identified in Hole C0008A, 114.5-127.5 m CSF (2865.5-2878.5 mbsl) and 129.5-150 m CSF (2880.5-2901 mbsl), separated by a $\sim 2 \mathrm{~m}$ wide interval mainly constituted of detrital iron oxides (PSD-MD magnetite) (Fig. 2).

Single-domain (SD) greigite is the main magnetic iron sulfide identified over the interval studied from the analysis of the FORC diagrams. SD pyrrhotite is identified at $\sim 2887$ and $\sim 2891$ mbsl.

The observations made in Hole C0008A differ from Hole C0008C (Kars and Kodama 2014, 2015). Indeed, two IS layers are identified in Hole C0008A whereas six IS zones are identified in Hole C0008C. $\mathrm{D}_{\mathrm{JH}}$ is higher in Hole C0008A indicating that there is a higher proportion of finegrained SD ferrimagnetic minerals in Hole C0008A compared to Hole C0008C. The values of $\mathrm{M}_{\mathrm{rs}} / \mathrm{X}$ up to $\sim 220 \mathrm{kA} /$ m, i.e., $\sim 10$ times higher than in Hole C0008C, suggest that greigite content is higher in Hole C0008A. Hole C0008A samples also display higher values of the $\mathrm{ARM} / \mathrm{X}$ ratio (>120 A/m against $\sim \mathrm{A} / \mathrm{m}$ for Hole C0008C). Except for the 2869-2873.5 mbsl interval in Hole C0008C, referred as IS1 in Kars and Kodama (2015), all the IS intervals in Hole
C0008C are characterized by lower values of $\mathrm{IRM}_{0.9} / \mathrm{X}$, compared to Hole C0008A.

Greigite is more abundant than pyrrhotite in both Holes C0008A and C0008C. The conditions for the formation and preservation of greigite and pyrrhotite differ. Limited organic carbon (which limits microbial production of dissolved sulfide) and high concentration of reactive iron favor the preservation of greigite, whereas more reducing environments with higher $\mathrm{H}_{2} \mathrm{~S}$ concentration and more important organic matter consumption favor pyrrhotite (Kao et al. 2004). Moreover, their occurrence depends also on the sediment grain size. Greigite occurs mainly in fine-grained sediments, whereas pyrrhotite is present in coarser grained sediments (Horng et al. 1998). In the following paragraph, the differences in the magnetic mineralogy, i.e., greigite versus pyrrhotite, are not taken into account for understanding the distribution of the IS layers at Site C0008.

\section{Possible leads for the distribution of the IS layers}

The rock magnetic study conducted in Hole C0008A shows different results compared to Hole C0008C. The most important finding is the difference in the spatial distribution of the IS layers. In the following, possible leads that may explain this distribution are proposed.

\section{Mineralogical/lithological variations}

The simplest explanation for the differences in Holes C0008A and C0008C is variations in lithology (e.g., substrate type, nature, and abundance of clays). In Hole 
C0008A, the clay content of the studied interval is constant at $\sim 50 \%$. The calcite content is very low ( $<15 \%)$; quartz and plagioclase contents are $20-25 \%$ and quasiconstant (Expedition 316 Scientists 2009) (Fig. 8). The homogeneity of the dominant mineralogy is nevertheless not mirrored in the mineral abundance in the detrital clay size fraction $(<2 \mu \mathrm{m})$ (Guo and Underwood 2012). Illite is the dominant mineral $(>30 \%)$ in the $<2 \mu \mathrm{m}$ fraction and presents a decreasing downcore trend from $35 \%$ (at $2866 \mathrm{mbsl}$ ) to $30 \%$ (at $2907 \mathrm{mbsl}$ ). This trend is mirrored by a downcore increasing trend of smectite abundance (from $28 \%$ at $\sim 2866 \mathrm{mbsl}$ to $36 \%$ at $\sim 2907 \mathrm{mbsl}$ ). Smectite is the second more abundant mineral in the clay size fraction. Chlorite, quartz, and kaolinite contents are 20,10 , and $6 \%$ average, respectively (Guo and Underwood 2012). In the Nankai Trough, smectite is the mineral that varies the most in the $<2 \mu \mathrm{m}$ fraction. However, changes in detrital clays assemblage reflect depositional age of the host sediment rather than diagenetic processes (Guo and Underwood 2012 and references therein). Pliocene and Pleistocene sediments are enriched in detrital illite and chlorite, whereas Miocene deposits contain more smectite. This is likely due to a change in sediments provenance (Izu Bonin volcanic arc in Miocene versus Japan metamorphic mountain belts in Pliocene-Pleistocene) (Underwood and Steurer 2003).

The trends of the mineral abundance in the studied interval in Hole C0008A for the clay size fraction are similar to the trends identified in the studied interval in Hole C0008C (Fig. 8). Because the studied intervals cover a time interval of $\sim 120 \mathrm{kyr}$, it is reasonable to assume that the detrital clay assemblage does not differ significantly in the sediments. The IS layers recognized in both holes are not characterized by any significant changes in clays assemblage, compared to the non-IS layers.

However, as stated above, the availability of reactive iron is very important for the formation of iron sulfides. It might be possible that a secondary non-identified source of iron (e.g., Fe-rich silicates such as glauconite) is present. Indeed, it has been shown previously that glauconite is often associated with iron sulfides (Shipboard Scientific Party 1994).

\section{Grain size variations}

Clay and silt are the dominant lithologies in the studied interval of Hole C0008A (Kopf et al. 2011) and represent $\sim 35$ and $\sim 55 \%$, respectively of the grain size distribution. Approximately ten percent correspond to the sand fraction. There is no particular enrichment in one or the other grain size fraction, with respect to the occurrence of the IS layers. Finer and coarser fractions alternate over the studied interval (Kopf et al. 2011).

Physical properties measurements are another way to indicate lithological variations (e.g., natural gamma ray radiation, magnetic susceptibility) and grain size (e.g., gamma ray attenuation, porosity) and provide also information on state of consolidation, deformation, and strain. The wet bulk density measured by gamma ray attenuation increases downhole from $\sim 1.60 \mathrm{~g} / \mathrm{cm}^{3}$ just below seafloor to $1.95 \mathrm{~g} / \mathrm{cm}^{3}$ at $\sim 3023 \mathrm{mbsl}$ in Hole C0008A (Expedition 316 Scientists 2009). The slight variations of the bulk density in the studied intervals at Site C0008 (i.e., 2867-2907 mbsl in Hole C0008C and 2861$2904 \mathrm{mbsl} \mathrm{m}$ CSF in Hole C0008A) are not significant to explain the occurrence of the IS layers.

In addition to the given P-T conditions and methane content for the formation of gas hydrate, porosity is considered

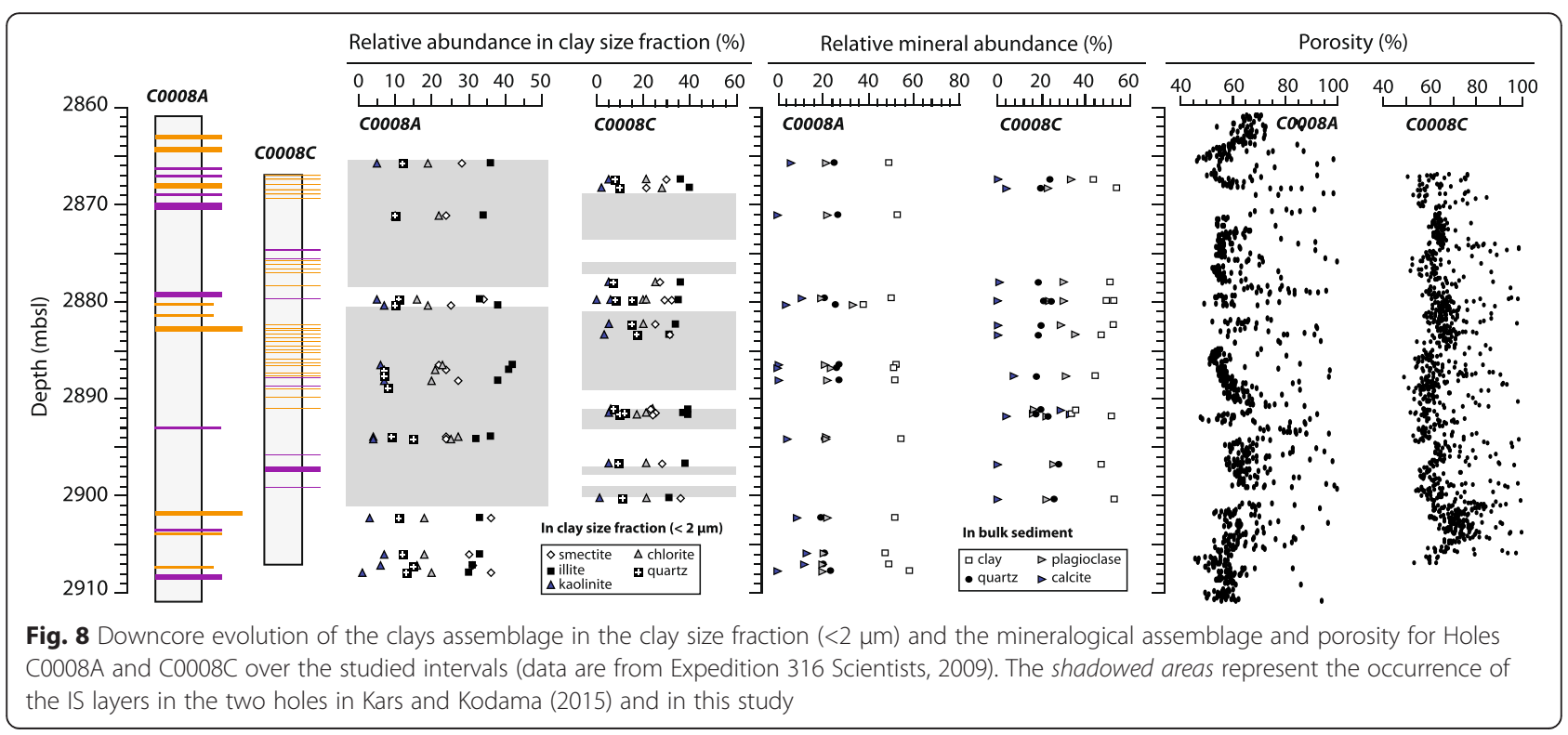


as an important factor favoring the formation and concentration of gas hydrate (e.g., Ginsburg et al. 2000; Jin et al. 2002). High porosity should favor occurrence of gas hydrate. Porosity decreases monotonically downhole from $\sim 63 \%$ just below seafloor to $\sim 47 \%$ at $\sim 3021 \mathrm{mbsl}$ in Hole C0008A (Expedition 316 Scientists 2009). Expedition 316 Scientists do not observe significant deviations from the downhole trend. Moreover, porosity does not show any particular trend related to the occurrence of the IS layers. In Hole C0008C, porosity does not vary significantly over the studied interval ( $\sim 60 \%)$, although higher value ( 65\%) intervals are present (Fig. 8). In Hole C0008A, porosity is also $\sim 60 \%$, except for the $\sim 2889-2906$ mbsl interval where porosity is $\sim 65 \%$ on average (Fig. 8). The intervals that present higher measured porosity values host ferrimagnetic iron sulfides in both holes. Because the overall slightly decreasing trend of porosity cannot explain the spatial distribution of the IS layers, the possibility that localized slight changes in porosity occur cannot be ruled out. The intervals with higher porosity would favor the formation of gas hydrate leading to the formation of ferrimagnetic iron sulfides.

\section{Methane content and microbial activity}

At Site C0008, the occurrence of ferrimagnetic iron sulfides is associated with gas hydrate. It is reasonable to assume that the gas content may play a role on the distribution of the IS layers.

Below the sulfate-methane transition zone (at $\sim 4-8 \mathrm{~m}$ below sea floor in Holes C0008A and C0008C), the methane concentration decreases to $\sim 2 \mathrm{mM}$ at $60 \mathrm{~m}$ depth and remains at this value downhole (Expedition 316 Scientists 2009). Exception is a local enrichment up to $15 \mathrm{~m} \mathrm{M}$ at $\sim 140 \mathrm{~m}$ CSF $(\sim 2891 \mathrm{mbsl})$ in Hole C0008A. This corresponds to a pore water anomaly (low chlorinity) that indicates the occurrence of gas hydrate. Then changes in methane concentration over the studied intervals cannot explain the distribution of the IS layers. Gas hydrates are rather disseminated throughout the holes, rather than being localized at some particular depth intervals.

In the Nankai Trough, $\mathrm{CH}_{4}$ formation is mainly by microbial hydrogenotropic methanogenesis (Toki et al. 2012). Methanogenic Archaea are inactive below $100 \mathrm{~m}$ depth and prevent organic matter decomposition (Toki et al. 2012). Because organic matter content is low over the studied intervals $(<0.6 \%$; Expedition 316 Scientists 2009), organic matter is not the main factor controlling the magnitude of hydrogenotropic methanogenesis (Toki et al. 2012). Presence of gas hydrate enhances microbial activity that results in the formation of ferrimagnetic iron sulfides (high values of $\mathrm{D}_{\mathrm{JH}}$ ), as shown by lower concentration of pyrite and higher concentration of iron monosulfides (mainly greigite) in the studied intervals in Holes C0008A and C0008C (Riedinger and Brunner 2014).
The microbial cell abundance is almost double in Hole C0008C, compared to Hole C0008A (Expedition 316 Scientists 2009). More gas hydrate occurrences and IS layers are identified in Hole C0008C, compared to Hole C0008A, but the total width covered by the IS layers is lesser (17.3 against $33.5 \mathrm{~m})$. At the authors' knowledge, no interpretation has been given yet for the distinct microbial content, which could be a probable explanation for clarifying the distribution of the IS layers at Site C0008, as a result of probable different environmental and geochemical conditions prevailing in the two holes.

Two thick IS layers, covering almost entirely the sampling interval, are then recognized in Hole C0008A, whereas six IS layers were identified in Hole C0008C for roughly the same depth interval in Mid Pleistocene sediments. One has to keep in mind that the age of the host sediments is not the age of gas hydrate formation (Kars and Kodama 2015). The IS intervals are not uniform laterally. So will be the gas hydrate horizons, by assuming the IS layers as potential reservoirs of gas hydrates. The conditions controlling the formation of the ferrimagnetic iron sulfides then differ between the two boreholes, although the mechanism(s) responsible could be the same. This indicates that not only are the pressuretemperature conditions responsible for the formation of ferrimagnetic iron sulfides and gas hydrates but also environmental (diagenetic) and geochemical conditions (e.g., redox conditions, reactive iron) as a result of possible microbially mediated process.

\section{Conclusions}

The rock magnetic study conducted from 110 to $153 \mathrm{~m}$ CSF in Hole C0008A in the Nankai Trough highlighted a widespread occurrence of magnetic iron sulfides, particularly greigite. Two thick IS layers, containing greigite and pyrrhotite, were identified both associated with the occurrence of gas hydrate. In the neighboring Hole C0008C, six IS layers were identified for the same lateral horizon, all corresponding to gas hydrate-bearing horizons. Both holes present also distinct magnetic properties that result from diagenesis. Possible leads for explaining the spatial distribution of the IS layers at Site C0008 were proposed. However, to date, no satisfying explanation can be expressed to report the occurrence of the multiple IS layers. It is likely that a combination of many factors (availability of reactive iron, microbial activity) favor the formation of ferrimagnetic iron sulfides in the presence of gas hydrates. Future work on the role of the microbial activity in gas hydrate-bearing sediments, as well as on the factors controlling the formation of iron sulfides, is needed in order to better understand the relationship between gas hydrate and iron sulfide. 


\section{Additional file}

Additional file 1: Downcore evolution of the hysteresis properties of samples from Hole C0008A. Selected examples of slope-corrected hysteresis loops. On insert for Spl.13H-2-60-62 is shown the non-corrected hysteresis loop. All the hysteresis loops shown here correspond to samples presented in the main manuscript. Except for $\mathrm{Bc}>45 \mathrm{mT}$, there is a linear relation between Mrs/Ms. To the Production staff: Please note that " $c$ " in Bc, "rs" in Mrs and "s" in Ms should be in subscript.

\section{Competing interests}

The authors declare that they have no competing interests.

\section{Authors' contributions}

MK did the measurements and wrote the manuscript. KK contributed to the scientific discussions and the writing of the manuscript. Both authors read and approved the final manuscript.

\section{Acknowledgements}

Samples used in this study were provided by the Integrated Ocean Drilling Program (IODP). We would like to thank the Marine Works Japan staff for their help during the sampling party in Kochi Core Center.

We are grateful to Dr. Mark J. Dekkers and an anonymous reviewer for their constructive comments and to Dr. Qingsong Liu for editorial handling. This is contribution PMG15-04 from the Center for Advanced Marine Core Research, Kochi University.

\section{Received: 27 February 2015 Accepted: 30 June 2015}

Published online: 29 July 2015

\section{References}

Aben FM, Dekkers MJ, Bakker RR, van Hinsbergen DJJ, Zachariasse WJ, Tate GW, McQuarrie N, Harris R, Duffy B (2014) Untangling inconsistent magnetic polarity records through an integrated rock magnetic analysis: a case study on Neogene sections in East Timor. Geochem Geophys Geosyst 15(6):2531-2554. doi:10.1002/2014GC005294

Ashi J, Tokuyama H, Taira A (2002) Distribution of methane hydrate BSRs and its implication for the prism growth in the Nankai Trough. Mar Geol 187:177-191

Aubourg C, Pozzi J-P (2010) Toward a new $<250{ }^{\circ} \mathrm{C}$ pyrrhotite-magnetite geothermometer for claystones. Earth Planet Sci Lett 294(1-2):47-57

Chang L, Vassiliev I, van Baak C, Krijgsman W, Dekkers MJ, Roberts AP, Ftiz Gerald JD, van Hoesel A, Winklhofer M (2014) Identification and environmental interpretation of diagenetic and biogenic greigite in sediments: a lesson from the Messinian Black Sea. Geochem Geophys Geosyst 15:3612-3627. doi:10.1002/2014GC005411

Collett TS (2001) A review of well-log analysis techniques used to assess gas-hydrate bearing reservoirs. In: Paull CK and Dillon WP (eds) Natural gas hydrates: occurrence, distribution and detection. Geophysical Monograph Series 124:189-210. doi:10.1029/GM124p0189

Day R, Fuller M, Schmidt V (1977) Hysteresis properties of titanomagnetites: grain-size and compositional dependence. Phys Earth Planet Inter 13:260-267

Dekkers M, Mattéi JL, Fillion G, Rochette P (1989) Grain-size dependence of the magnetic behavior of pyrrhotite during its low-temperature transition at 34 K. Geophys Res Lett 16(8):855-858

Expedition 316 Scientists (2009) Expedition 316 Site C0008. In: Kinoshita M, Tobin H Ashi J, Kimura G, Lallement S, Screaton EJ, Curewitz D, Masago H, Moe KT, and the Expedition 314/315/316 Scientists (eds) Proc IODP, vol 314/315/316. Integrated Ocean Drilling Program Management International, Inc, Washington, DC. doi:10.2204/iodp.proc.314315316.136.2009

Ginsburg G, Soloviev V, Matveeva T, Andreeva I (2000) Sediment grain size control on gas hydrate presence, sites 994, 995 and 997. Proc Ocean Drill Prog Sci Results 164:237-245

Guo J, Underwood MB (2012) Data report: clay mineral assemblages from the Nankai Trough accretionary prism and the Kumano Basin, IODP Expeditions 315 and 316, NanTroSEIZE Stage 1. In: Kinoshita M, Tobin H, Ashi J, Kimura G, Lallement S, Screaton EJ, Curewitz D, Masago H, Moe KT, and the Expedition 314/315/316 Scientists (eds) Proc IODP, vol 314/315/316. Integrated Ocean Drilling Program Management International, Inc, Washington, DC doi:10.2204/iodp.proc.314315316.202.2012
Harrison R, Feinberg J (2008) FORCInel: an improved algorithm for calculating first-order reversal curve distributions using locally weighted regression smoothing. Geochem Geophys Geosyst. 9. doi: 10.129/2008GC001987

Hesse R (2003) Pore water anomalies of submarine gas-hydrate zones as tool to assess hydrate abundance and distribution in the subsurface What have we learned in the past decade? Earth-Sci Rev 61:149-179

Horng CS, Torii M, Shea KS, Kao SJ (1998) Inconsistent magnetic polarities between greigite- and pyrrhotite/magnetite-bearing marine sediments from the Tsailiao-chi section, southwestern Taiwan. Earth Planet Sci Lett 164:467-481

Housen BA, Musgrave RJ (1996) Rock-magnetic signature of gas hydrates in accretionary prisms sediments. Earth Planet Sci Lett 139:509-519

Jin YK, Lee MW, Collett TS (2002) Relationship of gas hydrate concentration to porosity and reflection amplitude in a research well, McKenzie Delta, Canada. Mar Petrol Geol 19:407-415

Kao SJ, Horng CS, Roberts AP, Liu KL (2004) Carbon-sulfur-iron relationships in sedimentary rocks from southwestern Taiwan: influence of geochemical environment on greigite and pyrrhotite formation. Chem Geol 203:153-168

Kars M, Kodama K (2014) Occurrence of iron sulfides-rich layers and gas hydrates horizons in Site C0008, Nankai Trough. AOGS Meeting 2014, Sapporo (Japan), July 28th-August $1^{\text {st }}$, SE04-A018

Kars M, Kodama K (2015) Authigenesis of magnetic minerals in gas hydratebearing sediments in the Nankai Trough, offshore Japan. Geochem Geophys Geosyst. 16. doi:10.1002/2014GC005614.

Kars M, Aubourg C, Pozzi JP (2011) Low temperature magnetic behaviour near 35 K in unmetamorphosed claystones. Geophys J Int 186:1029-1035

Kennett JP, Cannariato KG, Hendy IL, Behl RJ (2003) Methane hydrates in quaternary climate change: the clathrate gun hypothesis. American Geophysical Union 54:216

Kimura G, Moore GF, Strasser M, Screaton E, Curewitz D, Streiff C, Tobin H (2011) Spatial and temporal evolution of the megasplay fault in the Nankai Trough. Geochem Geophys Geosyst 12(3):Q0A008. doi:10.1029/2010GC003335

Kinoshita M, Tobin H, Ashi J, Kimura G, Lallement S, Screaton EJ, Curewitz D, Masago H, Moe KT, the Expedition 314/315/316 Scientists (2009) Proc. IODP, 314/315/316. Integrated Ocean Drilling Program Management International, Inc, Washington, DC. doi:10.2204/iodp.proc.314315316.2009

Kinoshita M, Moore GF, Kido YN (2011) Heat flow estimated from BSR and IODP borehole data: Implication of recent uplift and erosion of the imbricate thrust zone in the Nankai Trough off Kumano. Geochem Geophys Geosyst 12(9):Q0AD18. doi:10.1029/2011GC003609

Kinoshita M, Fukase H, Goto S, Toki T (2015) In situ thermal excursions detected in the Nankai Trough forearc slope sediment at IODP NanTroSEIZE Site C0008. Earth Planets and Space 67:16. doi:10.1186/s40623-014-0171-1

Kopf A, Strasser M, Monsees N, Underwood M, Guo J (2011) Data report: particle size analysis of sediments recovered during IODP Expeditions 315 and 316, Sites C0001-C0008, Nankai Trough forearc, off Japan. In: Kinoshita M, Tobin H, Ashi J, Kimura G, Lallemant S, Screaton EJ, Curewitz D, Masago H, Moe KT, the Expedition 314/315/316 Scientists (eds) Proc. IODP, 314/315/316. Integrated Ocean Drilling Program Management International, Inc, Washington, DC. doi:10.2204/iodp.proc.314315316.207.2011

Kvenvolden KA (1993) Gas hydrates-geological perspective and global change. Rev Geophys 31(2):173-187

Larrasoaña JC, Gràcia E, Garcés M, Musgrave RJ, Piñero E, Martínez-Ruiz F, Vega ME (2006) Rock magnetic identification of magnetic iron sulfides and its bearing on the occurrence of gas hydrates, ODP Leg 204 (hydrate ridge). In: Tréhu AM, Bohrmann G, Torres ME, Colwell FS (eds) Proc. ODP, Sci. Results 204., pp 1-33

Larrasoaña JC, Roberts AP, Musgrave RJ, Gràcia E, Piñero E, Vega M, Martinez-Ruiz F (2007) Diagenetic formation of greigite and pyrrhotite in gas hydrate marine sedimentary systems. Earth Planet Sci Lett 261:350-366

Moskowitz B, Frenkel RB, Bazylinski DA (1993) Rock magnetic criteria for the detection of biogenic magnetite. Earth Planet Sci Lett 120:283-300

Musgrave RJ, Bangs NL, Larrasoaña JC, Gràcia E, Hollamby JA, Vega ME (2006) Rise of the base of the gas hydrate zone since the last glacial recorded by rock magnetism. Geology 34(2):117-120. doi:10.1130/G22008.1

Muxworthy AR, McClelland E (2000) Review of the low-temperature magnetic properties of magnetite from a rock magnetic perspective. Geophys J Inter 140:101-114

Özdemir O, Dunlop D, Moskowitz B (2002) Changes in remanence, coercivity and domain state at low-temperature in magnetite. Earth Planet Sci Lett 194:343-358

Passier HF, Dekkers MJ (2002) Iron oxide formation in the active oxidation front above sapropel $\mathrm{S} 1$ in the eastern Mediterranean Sea as derived from lowtemperature magnetism. Geophys J Int 150:230-240 
Riedinger N, Brunner B (2014) Data report: concentration and sulfur isotope composition of iron monosulfide and pyrite from sediments collected during IODP Expedition 316. In: Kinoshita M, Tobin H, Ashi J, Kimura G, Lallemant S, Screaton EJ, Curewitz D, Masago H, Moe KT (eds) the Expedition 314/315/316 Scientists, Proc. IODP, 314/315/316. Integrated Ocean Drilling Program Management International, Inc, Washington, DC. doi:10.2204/iodp. proc.314315316.223.2014

Roberts AP (1995) Magnetic properties of sedimentary greigite $\left(\mathrm{Fe}_{3} \mathrm{~S}_{4}\right)$. Earth Planet Sci Lett 134:227-236

Roberts AP, Pike CR, Verosub KL (2000) First-order reversal curve diagrams: a new tool for characterizing the magnetic properties of natural samples. J Geophys Res 105(B12):28,461-28,475

Roberts AP, Liu Q, Rowan CJ, Chang L, Carvallo C, Torrent J, Horng CS (2006) Characterization of hematite $\left(a-\mathrm{Fe}_{2} \mathrm{O}_{3}\right)$, goethite $(\mathrm{a}-\mathrm{FeOOH})$, greigite $\left(\mathrm{Fe}_{3} \mathrm{~S}_{4}\right)$, and pyrrhotite $\left(\mathrm{Fe}_{7} \mathrm{~S}_{8}\right)$ using first-order reversal curve diagrams. J Geophys Res 111:B12S35. doi:10.1029/2006JB004715

Roberts AP, Chang L, Rowan CJ, Horng CS, Florindo F (2011) Magnetic properties of sedimentary greigite $\left(\mathrm{Fe}_{3} \mathrm{~S}_{4}\right)$ : an update. Rev Geophys 49:RG1002. doi:10.1029/2010RG000336

Roberts AP, Heslop D, Zhao X, Pike CR (2014) Understanding fine magnetic particle systems through use of first-order reversal curve diagrams. Rev Geophys 52:557-602. doi:10.1002/2014RG000462

Rochette P, Fillion G, Mattéi JL, Dekkers MJ (1990) Magnetic transition at 30-34 Kelvin in pyrrhotite: insight into a widespread occurrence of this mineral in rocks. Earth Planet Sci Lett 98:319-328

Shipboard Scientific Party (1994) Sites 889 and 890. In: Westbrook GK, Carson B, Musgrave RJ et al (eds) Proceedings of the ocean drilling program, initial reports 146, part 1. Ocean Drilling Program, College Station, TX, pp 127-239

Strasser M, Moore GF, Kimura G, Kopf AJ, Underwood MB, Guo J, Screaton EJ (2011) Slumping and mass transport deposition in the Nankai fore arc: evidence from IODP drilling and 3-D reflection seismic data. Geochem Geophys Geosyst 12(5):Q0AD13. doi:10.1029/2010GC003431

Toki T, Uehara Y, Kinjo K, ljiri A, Tsunogai U, Tomaru H, Ashi J (2012) Methane production and accumulation in the Nankai accretionary prism: results from IODP Expeditions 315 and 316. Geochem J 46:89-106

Underwood MB, Steurer JF (2003) Composition and sources of clay from the trench slope and shallow accretionary prism of Nankai Trough. In: Mikada $\mathrm{H}_{\text {}}$ Moore GF, Taira A, Becker K, Moore JC, Klaus A (eds) Proc. ODP, Sct. Results, 190/196., pp 1-28

Wehland F, Stancu A, Rochette P, Dekkers MJ, Appel E (2005) Experimental evaluation of magnetic interaction in pyrrhotite bearing samples. Phys Earth Planet Inter 153:181-190

Wolfers P, Fillion G, Ouladdiaf B, Ballou R, Rochette P (2011) The pyrrhotite 32 K magnetic transition. Solid State Phenom 170:174-179

Yamano M, Kawada Y, Hamamoto H (2014) Heat flow survey in the vicinity of the branches of the megasplay fault in the Nankai accretionary prism. Earth Planets Space 66:126. doi:10.1186/1880-5981-66-126

Zhao X, Kitamura Y (2011) Data report: magnetic property studies of sediments and rocks from IODP Expedition 316. In: Kinoshita M, Tobin H, Ashi J, Kimura G, Lallemant S, Screaton EJ, Curewitz D, Masago H, Moe KT, the Expedition 314/315/316 Scientists (eds) Proc. IODP, 314/315/316. Integrated Ocean Drilling Program Management International, Inc, Washington, DC. doi:10.2204/iodp.proc.314315316.215.2011

\section{Submit your manuscript to a SpringerOpen ${ }^{\odot}$ journal and benefit from:}

- Convenient online submission

- Rigorous peer review

- Immediate publication on acceptance

- Open access: articles freely available online

- High visibility within the field

- Retaining the copyright to your article

Submit your next manuscript at $>$ springeropen.com 